Note

\title{
Oceanic survival and movements of wild and captive-reared immature green turtles (Chelonia mydas) in the Indian Ocean
}

\author{
Dominique Pelletier ${ }^{\mathrm{a}, *}$, David Roos ${ }^{\mathrm{b}}$, Stéphane Ciccione ${ }^{\mathrm{c}}$ \\ ${ }^{a}$ Lab. MAERHA, Institut Français de Recherche pour l'Exploitation de la Mer, IFREMER, BP 21105, 44311 Nantes cedex 3, France \\ ${ }^{b}$ IFREMER La Réunion, rue, Jean-Bertho, B.P. 60, 97822 Le Port cedex, France \\ ${ }^{c}$ Centre d'Etudes Des Tortues Marines (CEDTM), BP 40, 97436 St-Leu, France
}

Received 18 October 2002; accepted 2 December 2002

\begin{abstract}
The ability of captive-reared turtles to survive in the wild is not precisely known, nor are movements of immature turtles in the open ocean. To provide information on these issues, a satellite tracking experiment was conducted in the western Indian Ocean to monitor oceanic movements of immature green turtles. Two wild turtles and four captive-reared individuals were tracked. The latter had been displaced after birth from nesting sites to a distant rearing site. Wild turtles survived after release, but did not move far away from release site. We hypothesize that this resident behaviour may be explained by stage-specific habitat requirements. Captive-reared turtles survived after release and migrated over thousands of kilometres. Among these, the oldest immature turtles retrieved the foraging sites of their native population, with movement patterns similar to those displayed by adults. Observed movements may be linked to hydrographic conditions such as general oceanic circulation, sea temperature and thermal fronts.
\end{abstract}

(C) 2003 Éditions scientifiques et médicales Elsevier SAS and Ifremer/IRD/Inra/Cemagref. All rights reserved.

Keywords: Marine turtle; Chelonia mydas; Satellite telemetry; Migration pattern; Captive-reared; Indian Ocean

\section{Introduction}

Although protected sea turtle populations have critically declined over the last century, in particular due to destruction of nesting habitats, directed subsistence and commercial hunting, and harmful incidental fishing mortality (Eckert, 1995; Spotila et al., 2000). Conservation measures based on the knowledge of spatial distributions and migration patterns could help to reduce incidental catch by fisheries. Also, release of young animals caught as hatchlings and protected from predation and fishing during their first years has been envisaged as a way to enhance wild populations. However, the ability of captive-reared animals to survive release to the wild is not precisely known, nor are movements of immature turtles in the open ocean.

Sea turtles travel periodically throughout their life cycle. Mature individuals periodically migrate between breeding and foraging sites that may be thousands of kilometres apart. Immature green turtles (Chelonia mydas) leave the nesting

\footnotetext{
* Corresponding author.

E-mail address: dpellet@ifremer.fr (D. Pelletier).
}

site as hatchlings and live in the open ocean at least a year, sometimes associated with algae rafts (Carr and Meylan, 1980; Carr, 1987). During this pelagic stage, they are mostly carnivorous. Between 3 and 5 years of age, they move to coastal habitats, becoming omnivorous and then herbivorous (Bjorndal, 1985). The spatial distribution and migration patterns of immature sea turtles are thought to depend upon environmental factors like oceanic fronts and gyres (Carr, 1987; Polovina et al., 2000). However, movements of immature turtles are poorly understood, as they can only be observed when they depart their place of birth, or when they are incidentally caught by offshore fisheries (Polovina et al., 2000). Mark-recapture experiments traditionally used for adult turtles (Le Gall and Hughes, 1987; Limpus et al., 1992; Miller et al., 1998) require that animals bear tags for long periods, and that the probability of recapture is large enough to get a significant number of observations. Recapturing immatures in the ocean is problematic because they are small, widely distributed and suffer intense predation; consequently there are few such experiments conducted (Limpus et al., 1992; Wood and Wood, 1993). Like mark-recapture techniques, satellite tracking requires that transmitters do not 
alter health or behaviour. To date, it has mostly been used for breeding adults to study post-nesting migrations from nesting sites to foraging sites (Balazs et al., 1994; Cheng, 2000; Godley et al., 2002; Hatase et al., 2002; Hays et al., 2001; Hughes et al., 1998; Limpus and Limpus, 2001; Limpus et al., 1992; Luschi et al., 1996, 1998; Morreale et al., 1996; Mortimer and Balazs, 2000; Nichols et al., 2000; Papi et al., 1995; Roos et al., 2001). This methodology was also used for studying movements and diving behaviour on foraging areas or nesting areas (Godley et al., 2002; Hays et al., 1991, 1999, 2000, 2001; Renaud and Carpenter, 1994; Stoneburner, 1982) and seasonal migrations (Bentivegna, 2002). As for young turtles in the pelagic environment, the only reported satellite tracking experiment concerned wild loggerhead turtles (Caretta caretta) in the Pacific (Polovina et al., 2000). In the neritic environment, movements of juvenile turtles have been tracked from radio or sonic transmitters for loggerheads (Gitschlag, 1996; Timko and Deblanc, 1983) and for green turtles (Brill et al., 1995).

In addition to fishing and hunting mortality, immature turtles are subject to intense predation from birds and crustaceans at nesting sites, and from pelagic species in the ocean. In many countries, projects have been undertaken to enhance natural populations by growing hatchlings in captivity and releasing them into the wild (see review in Mortimer, 1995). Many projects were evaluated ineffectively, partly because methods to monitor released animals were lacking (but see Wood and Wood 1993). Furthermore, whether captivity affects the ability of turtles to survive in the ocean and to resume a natural migratory behaviour remains unknown (Mortimer, 1995).

In this paper, we report the findings of a satellite tracking experiment that is innovative in two respects: (i) it is the first reported experiment carried out on immature green turtles; and (ii) it is the first time turtles reared in captivity since their birth were released and monitored through satellite telemetry. The objectives of the experiment are to (i) evaluate the ability of turtles displaced from their birth place as hatchlings and reared in captivity to survive in their native environment; and (ii) study the movements of immature green turtles in the pelagic environment.

\section{Materials and methods}

\subsection{Selection of captive-reared turtles}

Hatchling green turtles were caught on Tromelin $\left(15^{\circ} 33 \mathrm{~S}\right.$ and $54^{\circ} 31$ E, Fig. 1 during summer, from 1989 to 1992 , and transferred to the laboratory in La Reunion $\left(21^{\circ} \mathrm{S}, 55^{\circ} \mathrm{E}\right)$, i.e. hundreds of kilometres away from their nesting site. They were placed in $20 \mathrm{~m}^{3}$ tanks and fed with floating granules (Biomar, Inc., France) for 5 years. Twenty healthy animals were selected for the experiment, and their ability to feed on natural food was first tested. They were fed various live or dead fish (Oreochromis mossambicus) weighing from 35 to $350 \mathrm{~g}$ each, squid (Loligo), small crabs (Grapsus) and land

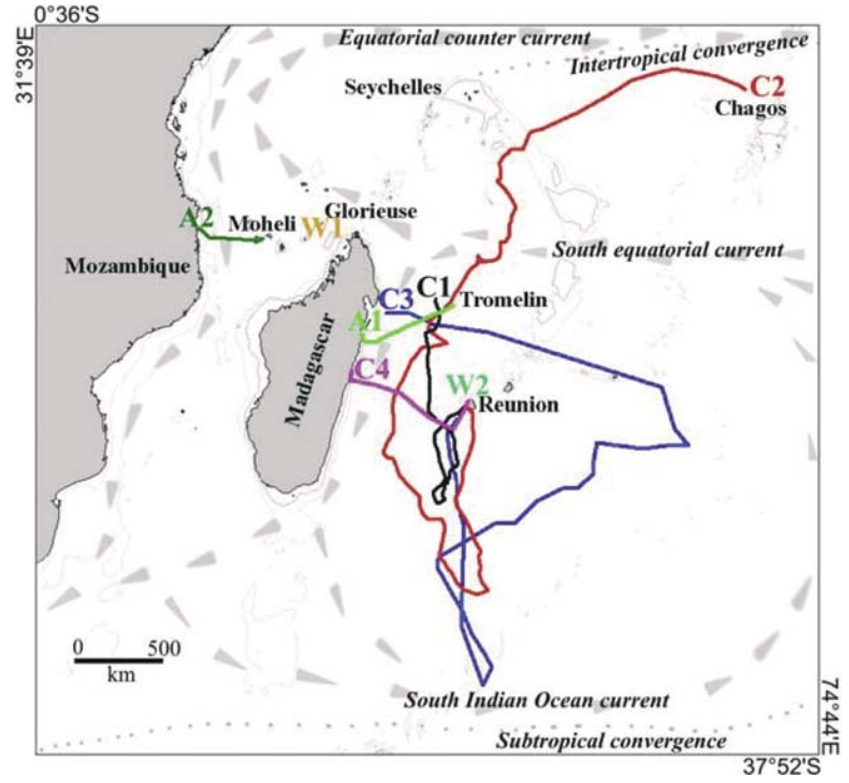

Fig. 1. Trajectories of tracked turtles (see Table 1 for details about turtles). Large-scale oceanic currents and convergence areas are also reported (gray arrows and dots, respectively) after Humbert-Droz and Jullien (1983).

vegetable (Scovea taccata). Four turtles could not feed on this food. After 6 or 7 weeks, they became motionless and stayed apart from other individuals. However, they were still reactive to human stimuli, and they did not lose weight. They resumed feeding when they were offered floating granules. We assumed these turtles would not be able to survive in the ocean. Note that these were the only individuals older than 8 years. In contrast, 16 individuals could be fed on natural food, and after 6 months, they were healthy with a weight either stable or increasing. In a final step aimed at dissociating human presence from feeding, these turtles were placed in individual tanks for 3 weeks with no other food than live fish. After this experiment, turtles were no longer attracted by human presence near their tank. We assumed they were ready to return to sea where they would hunt to eat.

\subsection{Selection of wild turtles}

We also tracked two wild immatures for comparison with captive-reared turtles. Turtle W1 was caught close to a nesting beach on Glorieuse Fig. 1. It was uninjured and could be released a few hours after being caught. Turtle W2 was incidentally injured and caught by fishermen offshore from La Reunion. It was healed in an individual tank at the laboratory for 6 months, being fed with live fish and dead squid.

\subsection{Tracking experiment}

Satellite transmitters manufactured by Telonics, Inc., (Mesa, Arizona, USA) were attached to four immatures out of the 16 captive-reared turtles, and two wild immatures Table 1.

Each satellite transmitter was attached on the dorsal carapace with fibre-glass cloth and resin following the technique 
Table 1

Turtles released and corresponding transmitters. Transmitters were manufactured by Telonics, Inc. (Mesa, Arizona, USA). Duration of the monitoring period mostly depends on duty cycle. For instance, due to on-continuously duty cycle, turtle C1 was precisely tracked, but only for 55 d. Turtle W2 was monitored only for $56 \mathrm{~d}$ because it was recaptured by fishermen and brought back to the laboratory for treatment. Transmitter weights are $200 \mathrm{~g}$ for ST-18, $325 \mathrm{~g}$ for ST-6, and $350 \mathrm{~g}$ for ST-10 transmitters. This corresponds to a proportion of body weight of $2.5 \%$ for W2, and at most $0.8 \%$ for the others. Adults are only reported for comparison with immatures. They were equipped with a transmitter after they laid eggs at nesting sites

\begin{tabular}{|c|c|c|c|c|c|c|}
\hline \multirow[t]{2}{*}{ Turtle } & \multirow[t]{2}{*}{ Birth place } & \multirow[t]{2}{*}{ Age (years) } & Curved carapace & \multirow[t]{2}{*}{ Weight (kg) } & \multirow[t]{2}{*}{ Transmitter type } & \multirow[t]{2}{*}{ Duty cycle } \\
\hline & & & Length $(\mathrm{cm})$ & & & \\
\hline $\mathrm{C} 1$ & Tromelin & 5 & 70 & 45.5 & ST-10 & Continuous \\
\hline $\mathrm{C} 2$ & Tromelin & 6 & 77 & 52.8 & ST-10 & $6 \mathrm{~h}$ on, $6 \mathrm{~h}$ off \\
\hline $\mathrm{C} 3$ & Tromelin & 9 & 69 & 45.0 & ST-18 & $6 \mathrm{~h}$ on, $30 \mathrm{~h}$ off \\
\hline $\mathrm{C} 4$ & Tromelin & 9 & 75 & 42.0 & ST-18 & $6 \mathrm{~h}$ on, $30 \mathrm{~h}$ off \\
\hline W1 & Unknown (wild turtle) & $4-5$ & 56 & Not measured & ST-18 & $6 \mathrm{~h}$ on, $30 \mathrm{~h}$ off \\
\hline W2 & Unknown (wild turtle) & $3-4$ & 44 & 7.7 & ST-18 & $6 \mathrm{~h}$ on, $30 \mathrm{~h}$ off \\
\hline A1 & Probably Tromelin & Mature female & - & Not measured & ST-6 & Continuous \\
\hline $\mathrm{A} 2$ & Probably Moheli & Mature female & - & Not measured & ST-18 & $6 \mathrm{~h}$ on, $30 \mathrm{~h}$ off \\
\hline
\end{tabular}

Table 2

Characteristics of trajectories followed by tracked turtles. The standard deviation of average speed is reported between parentheses, with the number of points (n) from which the average and standard deviation were calculated

\begin{tabular}{|c|c|c|c|c|c|}
\hline Turtle & Deployment date & Days monitored & Minimum distance traveled $(\mathrm{km})$ & Average speed $\left(\mathrm{km} \mathrm{h}^{-1}\right)$ & \\
\hline $\mathrm{C} 1$ & 25th March 1998 & 55 & 2485 & $2.44(1.65)(n=176)$ & \\
\hline $\mathrm{C} 2$ & 10th October 1998 & 158 & 6884 & $2.95(1.72)(n=531)$ & \\
\hline C3 & 1st August 2000 & 154 & 5833 & $1.70(0.60)(n=20)$ & \\
\hline W1 & 15th June 2000 & 156 & 11 & $0.02(0.013)(n=4)$ & \\
\hline W2 & 11th December 2000 & 56 & 94 & $0.85(1.67)(n=21)^{\mathrm{a}}$ & \\
\hline \multirow[t]{2}{*}{$\mathrm{C} 4$} & 11th December 2000 & 82 & 1017 & In open sea & $3.14(1.91)(n=35)$ \\
\hline & & & & On sea grass beds & $0.37(0.43)(n=7)$ \\
\hline \multirow[t]{3}{*}{ A1 } & 7th April 1998 & 30 & 1120 & On nesting site & $0.17(n=1)$ \\
\hline & & & & In open sea & $2.90(0.37)(n=9)$ \\
\hline & & & & On sea grass beds & $0.29(n=1)$ \\
\hline \multirow[t]{3}{*}{$\mathrm{A} 2$} & 10th May 2001 & 113 & 608 & On nesting site & $0.23(0.28)(n=12)$ \\
\hline & & & & In open sea & $0.68(0.75)(n=5)$ \\
\hline & & & & On sea grass beds & $0.10(0.04)(n=4)$ \\
\hline
\end{tabular}

${ }^{a}$ These values mostly rely on two large speeds observed immediately after release, the turtle swimming away quite rapidly. When these values are excluded, the average speed falls down to 0.25 with a standard deviation of 0.46 .

described by Balazs et al. (1996). Transmitter weight ranges from 200 to $350 \mathrm{~g}$, depending on transmitter type (Table 1. The western Indian Ocean is covered by NOAA satellites NOAA-11, NOAA-12 and NOAA-14. Transmitter data were received and collected by the Argos CLS ${ }^{1}$ system, which classifies signal locations in six location classes (LC): 3, 2, 1, $0, \mathrm{~A}$ and $\mathrm{B}$. For LC greater or equal to 1 , accuracy is less than $1000 \mathrm{~m}$ in latitude and longitude, namely $<150 \mathrm{~m}$ for LC 3 , $<350 \mathrm{~m}$ for $\mathrm{LC} 2$, and $<1 \mathrm{~km}$ for LC 1 . No accuracy limit is available for LC 0 . Locations in LC A and B are based on a lesser number of signals, and were thus excluded from results. Only fixes in classes $0,1,2$ and 3 were retained for computing distances travelled and swim speeds. We did not distinguish signals received during day time from those received at night. In addition to transmitters, a Monel tag, and a passive integrated transponder were fixed on the right anterior flipper of each individual to identify turtles upon recapture after the transmitter stopped operating.

\footnotetext{
${ }^{1}$ Argos CLS, 2002. User's manual. http://www.cls.fr/manuel_fr/
}

Six immature turtles were released from March 1998 to December 2000 (see Tables 1 and 2 for details). Turtles grown in captivity (C1-C4) were released from La Reunion at different times of the year to examine their movements in response to environmental variables. Their age is perfectly known Table 1 since they were caught as hatchlings. Although C1-C4 were approximately of the same size, C3 and $\mathrm{C} 4$ were close to sexual maturity. The wild turtle W2 was released the same day as $\mathrm{C} 4$ to compare their behaviour. Apart from W2, each turtle was kept in a tank for $2 \mathrm{~d}$ to check that behaviour was not perturbed by the transmitter. Although this was apparently not the case, we cannot formally exclude the possibility of perturbations of movement energetics and turtle's maneuverability (Watson and Granger, 1998).

In addition to immatures, we here report results from another tracking experiment on two nesting females (A1 and A2) undertaking their post-nesting migration from nesting sites (Tromelin and Moheli) to foraging sites Fig. 1). These results will be used for comparison with the oldest immature turtles $\mathrm{C} 3$ and $\mathrm{C} 4$. 


\subsection{Computation of distances and speeds}

The distance travelled between two successive signal locations 1 and 2 was estimated from the classical equation:

$$
\begin{aligned}
& d\left(x_{1}, x_{2}\right)=\text { Radius } a \cos \left(\sin \left(\text { lat }_{1}\right) \sin \left(\text { lat }_{2}\right)\right. \\
& \left.+\cos \left(\text { lat }_{1}\right) \cos \left(\text { lat }_{2}\right) \cos \left(\text { lon }_{1}-\text { lon }_{2}\right)\right)
\end{aligned}
$$

where Radius is earth radius, and lat $_{i}$ and $l o n_{i}$ are latitude and longitude of signal location $i$. This distance is the minimum distance travelled between 1 and 2, since it assumes a straight trajectory. For each turtle, total distance travelled is obtained by summing distances between two successive valid signal locations over the tracking period.

Average speed between two successive signal locations is $d\left(x_{1}, x_{2}\right) /\left(t_{1}-t_{2}\right)$ where $\mathrm{t}_{1}$ and $\mathrm{t}_{2}$ are GMT times corresponding to emissions of signals 1 and 2. Due to inaccuracy in signal location, very close locations may result in unrealistic speed estimates. Speed values larger than $10 \mathrm{~km} \mathrm{~h}^{-1}$ were thus excluded. Average speed over the tracking period is the mean of average speeds between two successive signal locations. The trajectory of each turtle was established considering only the most precise location of each tracking day.

Note that distances and speeds are calculated with respect to ground, thereby including local currents.

\section{Results and discussion}

\subsection{Captive-reared turtles}

They immediately swam toward the ocean and steadily travelled long distances (average speed in open sea ranging from 1.7 to $3.14 \mathrm{~km} \mathrm{~h}^{-1}$ ) over the monitoring period (from 2 to 5 months). They first migrated southwards in the same direction as the southern bifurcation of the South Equatorial Current Fig. 1). C1, C2 and C3 travelled for 1 month in water temperatures of $27-28{ }^{\circ} \mathrm{C}$ before turning back northwards. In each case, the turn back coincides with the northwards progression of thermal fronts, local temperatures dropping $2-3{ }^{\circ} \mathrm{C}$ in the following days. During several days, $\mathrm{C} 1$ closely followed a thermal discontinuity separating water at $28{ }^{\circ} \mathrm{C}$ from water at $29^{\circ} \mathrm{C}$ (Fig. 2), before returning northwards.

$\mathrm{C} 1$ and $\mathrm{C} 2$ continued travelling northwards into the South Equatorial Current Fig. 1) and passed very close to their birth place, Tromelin. Unfortunately, turtle's C1 transmitter stopped emitting for unknown reasons around this period. C2 finally reached the Chagos archipelago after travelling 6884 $\mathrm{km}$. During the last (eastwards) leg of the trajectory (9 d), its speed increased to an average of $4.97 \mathrm{~km} \mathrm{~h}^{-1}\left( \pm 1.01 \mathrm{~km} \mathrm{~h}^{-1}\right.$, $n=22$ ), travelling being facilitated by the Equatorial Countercurrent. On its way north and west, turtle C3 was swimming in the South Equatorial Current. C3 and C4 headed for Madagascar at the same time and at the same latitude Fig. 1. They swam straight to sea grass beds, which are the main foraging sites for adult green turtles born in Tromelin as

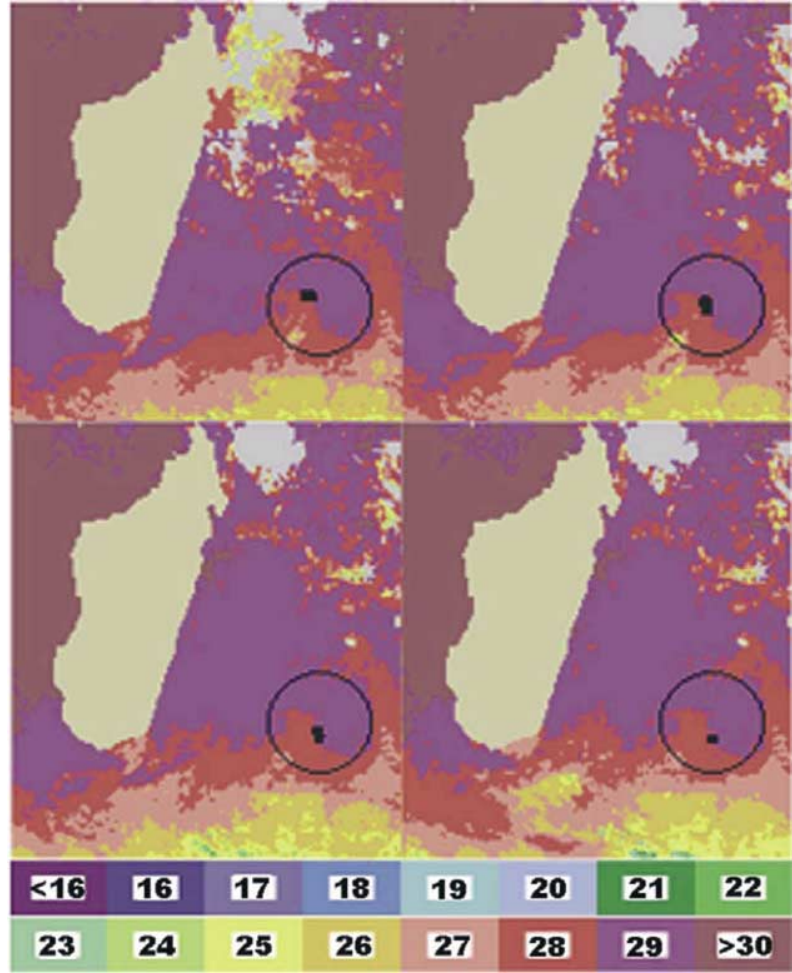

Fig. 2. Movements of turtle $\mathrm{C} 1$ and sea surface temperature (SST) between 4 and 8 April 1998 (top to bottom, then left to right). Turtle's locations are represented by black dots within a black circle. There are several locations per day due to on-continuously duty cycle of the transmitter. Sea Surface Temperature (SST) images were obtained from Advanced Very High Resolution Radiometer (AVHRR) transmitted NOAA satellites, and were provided by IRD La Reunion. The spatial resolution of the maps is approximately $2 \mathrm{~km}$ at the equator. In order to eliminate clouds and gaps left by satellites' trajectories, SST data are usually averaged over several days, $5 \mathrm{~d}$ in the present case. Although based on averages, SST maps reflect well short-term variations (Petit et al., 1994).

shown by mark-recapture (Le Gall and Hughes, 1987) and satellite tracking (e.g. turtle A1 on Fig. 1) experiments. After 3 weeks of directed movement, turtle $\mathrm{C} 4$ wandered on foraging sites for 2 months. Unlike the other turtles of the experiment, C3 and C4 were close to sexual maturity (Lutz and Musick, 1997), which may explain why their behaviour is similar to that of an adult. For comparison, adults A1 and A2 swam within a few days from their nesting site (Tromelin and Moheli) to their foraging site (Madagascar and Mozambique), where they remained for at least 2 and 8 weeks, respectively.

Our results suggest that green turtles grown in captivity are able to survive in the open ocean for months and travel long distances if they are released before they become sexually mature. During the feeding experiment at the laboratory, turtles that refused natural food stopped swimming after 6-7 weeks. The steady swimming activity displayed by tracked turtles throughout their oceanic travel demonstrates that they could feed at sea. In this respect, released turtles apparently show good adaptation to the oceanic environment. In another study, a loggerhead turtle maintained in captivity for 10 years 
was able to survive and travel for 1 year after release (Nichols et al., 2000).

Several of the movements we observed may be related to hydrological stimuli like ocean currents and thermal fronts. In the Pacific Ocean, young loggerhead turtles preferentially migrate between the subarctic and the subtropical gyres, in a zone spanned by a series of fronts (Polovina et al., 2000). Primary production in the western tropical Indian Ocean is generally low (Humbert-Droz and Jullien, 1983), but food for marine animals accumulates along thermal fronts, convergence and divergence areas (Yoder et al., 1994). These zones also concentrate various floating objects, algae (Carr, 1987) and debris (Nichols et al., 2000), which provide shelter for marine animals. More generally, high abundances of large pelagic species are often associated to hydrological discontinuities in the ocean, like fronts, eddies and upwellings (Fonteneau et al., 2000; Herron et al., 1989; Olson and Polovina, 1999; Power and May, 1991).

Our results also suggest that turtles grown in captivity and displaced from their birth place are able to retrieve the foraging sites of their native population. Furthermore, their route toward these sites is straight, and their movements once on foraging sites are quite similar to those of wild adults. Fidelity of marine turtles to foraging areas has already been demonstrated in several studies (Godley et al., 2002; Limpus and Limpus, 2001). It is thus likely that these turtles did not land by chance on these foraging areas. However, we could not identify climatic or hydrological conditions that explain why the oldest immature turtles we tracked moved toward foraging sites at the same time. Other external stimuli could help them to recognize the foraging sites of their population.

Based on these results and others (Lohmann and Lohmann, 1996; Morreale et al., 1996; Polovina et al., 2000), we hypothesize that sea turtles utilize several types of environmental cues for navigating in the ocean, including hydrological conditions. The specific hydrological characteristics of oceanic basins would then favour the geographic segregation of populations in each basin. In the western Indian Ocean, genetic analyses indeed distinguished only two populations, respectively east and west of Madagascar (Broderick, 2001). Under this hypothesis, a displaced turtle would be able to recover foraging and breeding sites of its population only if it is released in its native basin.

\subsection{Wild immature turtles}

In contrast to captive-reared turtles, the wild immatures remained close to the release site during monitoring, never travelling further than $9 \mathrm{~km}$ per day and at low speed $(<0.9$ $\mathrm{km} \mathrm{h}^{-1}$ ). Turtle $\mathrm{W} 1$ wandered around Glorieuse ( $3 \mathrm{~km}$ long) for 5 months and turtle W2 remained less than $2 \mathrm{~km}$ away from the release beach. These two turtles were smaller than the other turtles studied. In the Indian Ocean, small immature green turtles $(<30-40 \mathrm{~cm}$ CCL) are rarely seen on adult foraging sites (Musick and Limpus, 1997), but are frequently observed around islands like Reunion (Sauvignet et al., 2000), Comoros (Frazier, 1985), or the Seychelles (Frazier,
1984). These results indicate that these young immatures may reside for several months, possibly in association with coral reefs (Ogden, 1980). They corroborate the hypothesis that the reefs of such islands and nearby sea grass beds may constitute suitable habitats, allowing immature turtles to become omnivorous and eventually herbivorous, while providing relative shelter from oceanic predators (Musick and Limpus, 1997).

\section{Conclusion}

Young turtles grown in captivity are apparently perfectly able to survive and migrate in the ocean after release. However, their ability to retrieve breeding sites and reproduce successfully remains uncertain until recaptures on nesting sites are observed (Balazs et al., 2002).

In this experiment, the behaviour of these captive-reared immatures seemed unaltered after several years in captivity. Therefore, these observations shed light on the oceanic movements of immature green turtles in general. They appear capable of long-range movements in their pelagic environment. The oldest immature turtles join foraging areas and reside there like adults. The knowledge of movement trajectories together with additional information on diving behaviour and depth preferences should help to design appropriate conservation measures through reduction of incidental fishing mortality.

\section{Acknowledgements}

The authors thank George Balazs, Jean-Yves Le Gall, and an anonymous referee for encouraging comments and helpful suggestions on the first version of this paper. Financial support for this work was provided by the Minister of Overseas Territories (CORDET), and the Regional Council of La Reunion. The program benefits from long-term support from IFREMER. The CEDTM staff and Fabrice RENE helped out with laboratory experiments. The authors acknowledge the SEAS $^{2}$ Station, IRD Reunion for providing the Sea Surface Temperature images of Fig. 2

\section{References}

Balazs, G.H., Craig, P., Winton, B.R., Miya, R.K., 1994. Satellite telemetry of green turtles nesting of French fregate shoals, Hawaii, and Rose atoll, American Samoa. In: Bjorndal, K.A., Bolten, A.B., Johnson, D.A., Eliazar, P.J. (Eds.), Proceedings of the 14th annual Symposium on Sea Turtle Biology and Conservation. Dept Commerce. NOAA Tech. Memo. NMFS-SEFSC-351, U.S., pp. 184-186.

\footnotetext{
${ }^{2}$ Survey of Environment Assisted by Satellite Station, IRD (Research Institute for Development), La Reunion.
} 
Balazs, G.H., Miya, R.K., Beaver, S.C., 1996. Procedures to attach a satellite transmitter to the carapace of an adult green turtle, Chelonia mydas. In: Keinath, J.A., Barnard, D.E., Musick, J.A., Bell, B.A. (Eds.), Proceedings of the 15th Annual Symposium on Sea Turtle Biology and Conservation. NOAA Tech. Memo. NMFS-SEFSC-387, pp. 21-26.

Balazs, G.H., Nakai, G.L., Hau, S., Grady, M.J., Gilmartin, W.G., 2002. Year 2000 nesting of a captive-reared hawaïan green turtle tagged and released as a yearling. In: Abreu-Grobois, F.A., Briseno-Duenas, R., Marquez, R., Sarti, L. (Eds.), Proceedings of the 21st Annual Symposium on Sea Turtle Biology and Conservation. Dept Commerce. NOAA Tech. Memo. NMFS-SEFSC, U.S. (in press).

Bentivegna, F., 2002. Intra-Mediterranean migrations of loggerhead sea turtles (Caretta caretta) monitored by satellite telemetry. Mar. Biol. 202, 795-800.

Bjorndal, K.A., 1985. Foraging ecology and nutrition of sea turtles. In: Lutz, P.L., Musick, J.A. (Eds.), The Biology of Sea Turtles. CRC Press, Boca Raton, pp. 200-231.

Brill, R.W., Balazs, G.H., Holland, K.N., Chang, R.K.C., Sullivan, S., George, J.C., 1995. Daily movements, habitat use, and submergence intervals of normal and tumor-bearing juvenile green turtles (Chelonia mydas) within a foraging area in the Hawaiian islands. J. Exp. Mar. Biol. Ecol. 185, 203-218.

Broderick, D., 2001. Genetic differentiation among marine turtle rookeries in the Indian Ocean as inferred MtDNA sequence variation. In: Ciccione, S., Roos, D., Le Gall, J.Y. (Eds.), Knowledge and Conservation of Sea Turtles in the South-western Indian Ocean, Etudes et Colloques. CEDTM, La Réunion, pp. 70-71.

Carr, A.F., 1987. New perspectives on the pelagic stage of sea turtle development. Conserv. Biol. 1, 103-121.

Carr, A., Meylan, A.B., 1980. Evidence of passive migration of green turtle hatchlings in sargassum. Copeia 8, 366-368.

Cheng, I.J., 2000. Post-nesting migrations of green turtles (Chelonia mydas) at Wan-An Island, PengHu Archipelago, Taiwan. Mar. Biol. 137, 747-754.

Eckert, K.L., 1995. Anthropogenic threats to sea turtles. In: Bjorndal, K.A. (Ed.), Biology and Conservation of Sea Turtles. Smithsonian Institution Press, London, pp. 611-612 (revised edition).

Fonteneau, A., Pallarès, P., Pianet, R., 2000. A worlwide review of purse seine fisheries on Fish Aggregating Devices (FAD). In: Le Gall, J.Y., Cayré, P., Taquet, M. (Eds.), Pêche thonière et dispositifs de concentration de poisson, Actes de Colloques, IFREMER, 28, pp. 15-35.

Frazier, J., 1984. Marine turtles in the Seychelles and adjacent territories. In: Stoddart, D.R. (Ed.), Biogeography and Ecology of the Seychelles Islands, 55. Monogr. Biol. Natl. Zool. Park, Washington, pp. 417-468.

Frazier, J., 1985. Marine turtles in the Comoros Archipelago, North Holland, Amsterdam $177 \mathrm{p}$.

Gitschlag, G.R., 1996. Migration and diving behavior of Kemp's ridley (Garman) sea turtles along the U.S. southeastern Atlantic coast. J. Exp. Mar. Biol. Ecol. 205, 115-135.

Godley, B.J., Richardson, S., Broderick, A.C., Coyne, M.S., Glen, F., Hays, G.C., 2002. Long-term satellite telemetry of the movements and habitat utilisation by green turtles in the Mediterranean. Ecography 25, 352-362.

Hatase, H., Takai, N., Matsuzawa, Y., Sakamoto, W., Omuta, K., Goto, K., et al., 2002. Size-related differences in feeding habitat use of adult female loggerhead turtles Caretta caretta around Japan determined by stable isotope analyses and satellite telemetry. Mar. Ecol. Prog. Ser. 233, 273-281.

Hays, G.C., Adams, C.R., Broderick, A.C., Godley, B.J., Lucas, D.J., Metcalfe, J.D., et al., 2000. The diving behaviour of green turtles at Ascension Island. Anim. Behav. 59, 577-586.

Hays, G.C., Broderick, A.C., Glen, F., Godley, B.J., Nichols, W.J., 2001. The movements and submergence behaviour of male green turtles at Ascension Island. Mar. Biol. 139, 395-399.

Hays, G.C., Luschi, P., Papi, F., Del Seppia, C., Marsh, R., 1999. Changes in behaviour during the inter-nesting period and post-nesting migration for Ascension Island green turtles. Mar. Ecol. Prog. Ser. 189, 263-273.
Hays, G.C., Webb, P.I., Hayes, J.P., French, J., 1991. Satellite tracking of a loggerhead turtle (Caretta caretta) in the Mediterranean. J. Mar. Biol. Assoc. UK 71, 743-746.

Herron, H.C., Leming, T.D., Li, J., 1989. Satellite-detected fronts and butterfish aggregations in the northeast Gulf of Mexico. Cont. Shelf Res. $6,569-588$.

Hughes, G.R., Luschi, P., Mencacci, R., Papi, F., 1998. The 7000-km oceanic journey of a leatherback turtle tracked by satellite. J. Exp. Mar. Biol. Ecol. 22, 209-217.

Humbert-Droz, A., Jullien, D., 1983. Le grand atlas de la mer. Albin Michel, Paris.

Le Gall, J.Y., Hughes, G.R., 1987. Migrations de la tortue verte Chelonia mydas dans l'Océan Indien Sud-Ouest observées à partir des marquages sur les sites de ponte Europa et Tromelin (1970-1985). AmphibiaReptilia 8, 277-282.

Limpus, C.J., Limpus, D.J., 2001. The loggerhead turtle, Caretta caretta. In Queensland: Breeding migrations and fidelity to a warm temperate feeding area. Chelonian Conserv. Biol., 4, pp. 142-153.

Limpus, C.J., Miller, J.D., Parmenter, C.J., Reimer, D., McLachlan, N., Webb, R., 1992. Migration of green (Chelonia mydas) and loggerhead (Caretta caretta) turtles to and from eastern Australian rookeries. Wildl. Res. 19, 347-358.

Lohmann, K.J., Lohmann, C.M.F., 1996. Detection of magnetic field intensity by sea turtles. Nature $380,59-61$.

Luschi, P., Hays, G.C., Del Seppia, C., Marsh, R., Papi, F., 1998. The navigational feats of green sea turtles migrating from Ascension Island investigated by satellite telemetry. Proc. R. Soc. London Ser. B 265, 2279-2284.

Luschi, P., Papi, F., Liew, H.C., Chan, E.H., Bonadonna, F., 1996. Longdistance migration and homing after displacement in the green turtle (Chelonia mydas): a satellite tracking study. J. Comp. Physiol. A 178, 447-452.

Lutz, P.L., Musick, J.A., 1997. The Biology of Sea Turtles. CRC Press, Boca Raton.

Miller, J.D., Dobbs, K.A., Limpus, C.J., Mattocks, N., Landry Jr, A.M., 1998. Long-distance migrations by the hawksbill turtle, Eretmochelys imbricata, from north-eastern Australia. Wildl. Res. 25, 89-95.

Morreale, S.J., Standora, E.A., Spotila, J.R., Paladino, F.V., 1996. Migration corridor for sea turtles. Nature 384, 319-320.

Mortimer, J.A., 1995. Headstarting as a management tool. In: Bjorndal, K.A. (Ed.), Biology and Conservation of Sea Turtles. Smithsonian Institution Press, London, pp. 613-615 (revised edition).

Mortimer, J.A., Balazs, G., 2000. Post-nesting migrations of hawksbill turtles in the granitic Seychelles and implications for conservation. Proceedings of the 19th Annual Symposium on Sea Turtle Biology and Conservation. U.S. Dept Commerce. NOAA Tech. Memo. NMFSSEFSC-443, South Padre Island, pp. 22-26.

Musick, J.A., Limpus, C., 1997. Habitat utilization and migration in juvenile sea turtles. In: Lutz, P.L., Musick, J.A. (Eds.), The Biology of Sea Turtles. CRC Press, Boca Raton, , USA, pp. 137-163.

Nichols, W.J., Resendiz, A., Seminoff, J.A., Resendiz, B., 2000. Transpacific migration of a loggerhead turtle monitored by satellite telemetry. Bull. Mar. Sci. 67, 937-947.

Ogden, J.C., 1980. Faunal relationships in caribbean sea grass beds. In: Phillips, R.C., McRoy, C.P. (Eds.), Handbook of Sea Grass Biology: An Ecosystem Perspective. Garland STPM Press, New York, pp. 173-179.

Olson, D., Polovina, J.J., 1999. Proceedings of the Second International Pacific Swordfish Symposium. Local-scale swordfish fisheries oceanography, 263. NOAA Tech. Memo. NMFS-SWFSC-263, pp. 173-178.

Papi, F., Liew, H.C., Luschi, P., Chan, E.H., 1995. Long-range migratory travel of a green turtle tracked by satellite: evidence for navigational ability in the open sea. Mar. Biol. 122, 171-175.

Petit, M., Dagorn, L., Lena, P., Slepoukha, M., Ramos, A., Stretta, J.M., 1994. Oceanic landscape concept and operational fisheries oceanography. Mém. Inst. Oceanogr. Monaco 18, 85-97. 
Polovina, J.J., Kobayashi, D.R., Parker, D.M., Seki, M.P., Balazs, G.H., 2000. Turtles on the edge: movement of loggerhead turtles (Caretta caretta) along oceanic fronts, spanning longline fishing grounds in the central North Pacific, 1997-1998. Fish. Oceanogr. 1, 71-82.

Power, J.H., May, L.N.J., 1991. Satellite observed sea surface temperatures and yellowfin tuna catch and effort in the Gulf of Mexico. Fish. Bull. 3, 429-439.

Renaud, M.L., Carpenter, J.A., 1994. Movements and submergence patterns of loggerhead turtles (Caretta carreta) in the gulf of Mexico determined through satellite telemetry. Bull. Mar. Sci. 55, 1-15.

Roos, D., Ciccione, S., Ali, M., 2001. Genesic and trophic migrations of female green turtles in the south-west Indian Ocean. In: Ciccione, S., Roos, D., Le Gall, J.Y. (Eds.), Knowledge and Conservation of Sea Turtles in the South-western Indian Ocean, Etudes et Colloques. CEDTM, La Réunion, pp. 58-59.
Sauvignet, H., Pavitrin, A., Ciccione, S., Roos, D., 2000. Premiers résultats des campagnes de dénombrements aériens des tortues marines sur la côte Ouest et Sud de La Réunion. Phaeton 11, 8-18.

Spotila, J.R., Reina, R.D., Steyermark, A.C., Plotkin, P.T., Paladino, F.V., 2000. Pacific leatherback turtles face extinction. Nature 405, 529-530.

Stoneburner, D.L., 1982. Satellite telemetry of loggerhead sea turtle movement in the Georgia Bight. Copeia 2, 400-408.

Timko, R.E., Deblanc, D., 1983. Radio tracking juvenile marine turtles. Mar. Fish. Rev. 43, 20-24.

Watson, K.P., Granger, R.A., 1998. Hydrodynamic effect of a satellite transmitter on a juvenile green turtle (Chelonia mydas). J. Exp. Biol. 201, 2497-2505.

Wood, F., Wood, J., 1993. Release and recapture of captive-reared green sea turtles, Chelonia mydas, in the waters surrounding the Cayman Islands. Herpetol. J. 3, 84-89.

Yoder, J.A., Ackleson, S.G., Barber, R.T., Flament, P., Balch, W.M., 1994. A line in the sea. Nature 371, 689-692. 